\title{
Technological aspects of technogenic disturbance liquidation in the areas of coal-gas deposits development
}

\author{
Volodymyr Medianyk ${ }^{1 *}$, and Oleksii Cherniaiev ${ }^{2}$ \\ ${ }^{1}$ National Mining University, Department of Underground Mining, 19 Yavornytskoho Ave., \\ 49005 Dnipro, Ukraine \\ ${ }^{2}$ Institute for the Design of Mining Enterprises, National Mining University, 19 Yavornytskoho Ave., \\ 49005 Dnipro, Ukraine
}

\begin{abstract}
The objective of this work is to develop the technological measures for liquidation of technogenic disturbances that have arisen within the residential areas. Based on the results of geophysical studies, the causes and factors of Earth's surface caving occurrence that arose in the result of natural-technogenic processes activation in underworked massif and are caused by the soil subsidence under buildings and constructions, have been determined. The solution of the problem was carried out with the use of methods for observing the natural pulsed electromagnetic field of the Earth and electric tomography in the area adjacent to the place of caving. The conclusions about the possible causes of the caving trough formation and its further development have been formulated, as well as the technological scheme for its liquidation have been developed. The developed new technological scheme allows conducting the effective liquidation works in conditions of proximity to the residential buildings and maximally reduces these scopes of works at ecological and protective measures.
\end{abstract}

\section{Introduction}

Annually, from the Earth's interior in Ukraine, more than a billion cubic meters of the mined rock is extracted in the form of minerals and waste rock after preparatory mine workings development, which leads to the formation of cavity with appropriate sizes. In the area of old mines and underground mine workings location, as a result of naturaltechnogenic processes, the cavity is formed in disturbed rock massif after some extended period of time.

The specificity of the underground mining is in the fact that together with shut-down of ventilation and water pumping, the shifts activation takes place in the underworked rock massif due to its moistening. It causes additional deformations of buildings and constructions located in the area of liquidated mining industry facilities. In addition, water flooding can lead to hazardous methane gas release into the atmosphere without

\footnotetext{
*Corresponding author: vmedyanyk1975@gmail.com
} 
reclamation operation of underground mine workings.

The process of coal mines closure has intensified since the middle of the last century. The process of withdrawing mine workings from production has become more rapid, and in comparison with previous years in significant quantities. This is explained both by growing role of liquid and gaseous energy sources, large-scale implementation of nuclear energy, and by the fact that mining operations in traditional coal mining countries have reached such depths, where even with the application of new imported mining equipment and technologies, the coal mining costs often are not covered by revenues from its implementation [1].

The presence of many influencing factors, such as inability to control the processes occurring in the disturbed rock massif after mine working closure, the lack of models for formation and forecasting of the Earth's surface displacements leads to the cavity formation in regions significantly overloaded by coal mining enterprises [2 -5$]$.

It is a well-known fact that as a result of underground mining, there is a shift, deformations, and subsidence of rock massif. As a result of minerals mining under the overlying rocks the cavities are formed, and at the Earth's surface the subsidence troughs are formed. This is the initial rock massif disturbance and its regularities are well studied.

Thus, the necessity of liquidation of vertical mine workings is obvious. It is necessary to carry out the works of filling the mine shaft void space by noncombustible material, to construct the floors (floor slab panels) or stoppings, to use other means to shut-down the aerodynamic connection with operating mine workings, as well as to ensure the long-term stability of underground constructions and structures (fastening) for preventing the Earth's surface dangerous deformations.

The caving occurs suddenly and is unpredictable due to the fact that no one controls the rock massif state in the locations of old mines and mine workings. To predict the secondary disturbances of rock massif over the old mine workings, it is necessary to know the causes of the displacement processes manifestations (activation).

The objective of the work is to develop the technological measures for liquidation of technogenic disturbances that have arisen within the residential area in Dobropillia City (Ukraine). On the example of this object, the conditions of its formation have been considered and the technical solutions for the disturbed rock massif restoration, close to the natural state, have been proposed.

It is important to note that the technogenic disturbances liquidation in difficult conditions of soil slip processes should be carry out with account of the technologies that meet up-to-date requarements: use of special means and methods of performance of works, which will ensure a minimum impact on neighboring facilities, including mine workings that are in a stressed state [6]; use of rational schemes for waste rocks transportation, which minimize the specific energy intensity of the transportation processes of mined rock [7 -9]; conducting recultivation and revitalization of disturbed areas until the most environmentally acceptable landscape territories, as well as their regeneration $[11,12]$. It should also be noted the necessity to comply with ecological aspects of work performance with account of clean technologies development (Clean High Technologies) [13, 14].

\section{Methodology of project development}

To determine the causes and factors of technogenic disturbance occurrence that arose as a result of natural-technogenic processes activation in the underworked rock massif and have caused the soil subsidence under buildings and constructions, the methods for observing natural pulsed electromagnetic field of the Earth (NPEFE), electric tomography (ET), dismantling and cleaning water wells by subdivision of Ministry of Emergency Situations (MES), have been used. 
The application of the NPEFE observation method is substantiated by SNiP 1.02.07-87, and protected by authors' certificates and the State Patent of Ukraine [15].

The observations were carried out with the use of microprocessor-based indicator of spontaneous pulsed electromagnetic radiation of the Earth, a receiving antenna with a ferrite core and a system of amplification and registration blocks.

The NPEFE observation was carried out in accessible and safe areas on the territory of Dobropillia (Ukraine). The experimental observations were made in accordance with DBN A.2.1-1-2014. The observation profiles were located along the entire area in parallel to the streets, at a distance of $2.5 \mathrm{~m}$ from each other, bending round the permanent structures (apartment houses), auxiliary structures (cellars, sheds). The profiles position was related to the contours of buildings, fences, and the power transmission line supports. In total, 411 physical points have been worked out on this territory.

The processing of the measured values consists in interpolating the data for a regular network. The performance of two-dimensional filtration and drawing a scheme of NPEFE flow density are shown on Fig. 1.

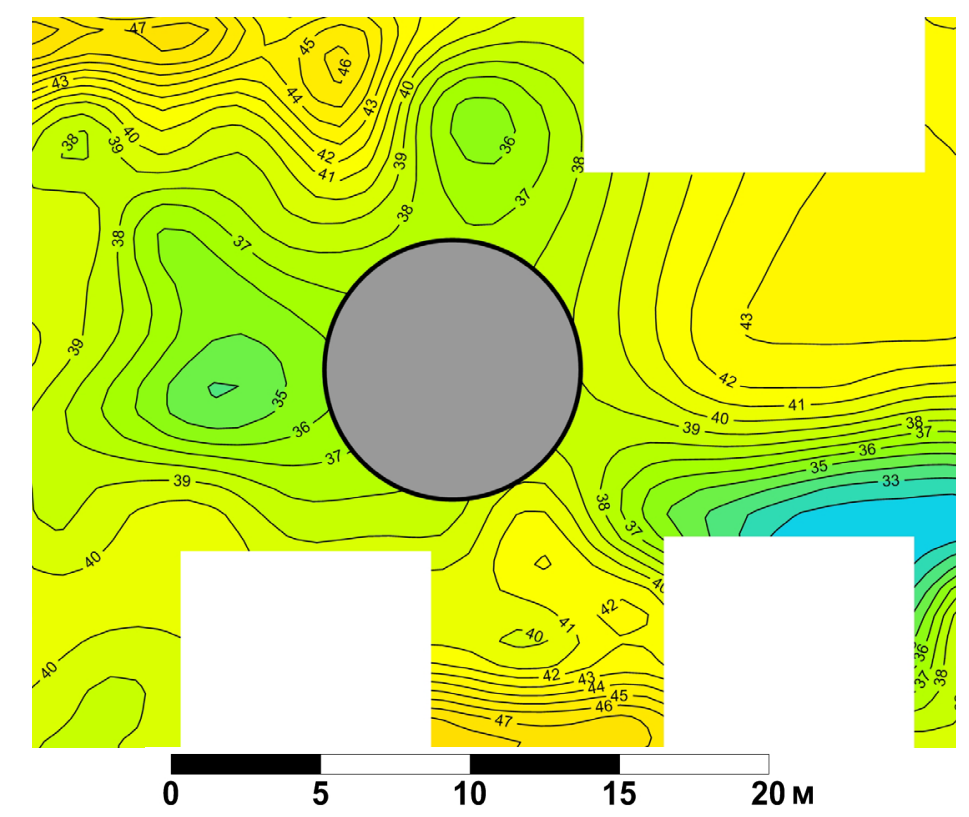

Fig. 1. Scheme of NPEFE flow density in a caving zone.

The application of electric tomography method was carried out in accordance with [16]. Electric tomography is a complex which includes both field observation techniques and the technology of processing and interpreting field data. Its feature is the repeated use of the same positions of electrodes, fixed on the observation profile, as a power supply and measuring instruments.

To study geoelectric sections, the use of electric tomography is a necessary criterion for reliable interpretation. Such a complex structure is usually characteristic of ore zones and zones with tectonic disturbances, landslides, bulked and artificial soils in urban areas, with a steep layers jump and with the occurrence of karst.

The fieldwork was carried out in accordance with the requirements of the electric inspection instruction by the method of resistance with the use of equally dipole axial installation. The measuring device EIN-209m was used as a receiver of an electromagnetic field at a frequency of $1.22 \mathrm{~Hz}$ in the receiving dipole. The dimensions of the receiving and 
feeding dipoles were $5 \mathrm{~m}$. The generator GER-1/300 was used as a power source.

According to the results of field measurements, a geoelectric section has been received (Fig. 2).

Geological section I-I'

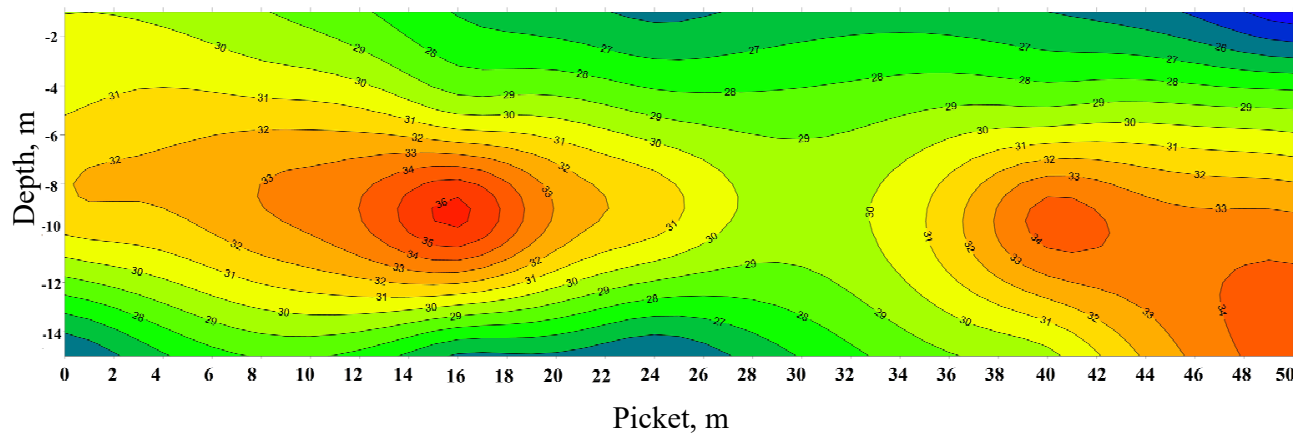

Fig. 2. The results of work by electric tomography method.

\section{Results and discussion}

\subsection{The results of the NPEFE observation}

The Fig. 1 shows the scheme of the NPEFE flow density at the territory adjacent to the caving zone. As can be seen from the scheme, the NPEFE flow density ranges within the limits of $37-51$ conventional units (c.u) and has a mosaic form in most of the surveyed area. In the area of the north-eastern corner of the building, an insignificant linearly elongated anomalous zone of reduced values can be observed, which can be explained by the existing leaks from the sewer thread. In the neighboring territory, a cavity formation has arisen, which has not a significant difference by a value of flow density. This may indicate that there was not a significant moistening of soils in the zone of cavity formation.

\subsection{The electric tomography results}

The Fig. 2 shows the geoelectrical section according to the observations. There is a steady increase in the value of specific resistance from 26 to $36 \mathrm{Ohm} \cdot \mathrm{m}$. In such a case, the upper part of the section - topsoil layer is characterized by the lowest values. At a depth of $3-$ $4 \mathrm{~m}$ in the zone of sandy loam occurrence the values of more than $30 \mathrm{Ohm} \cdot \mathrm{m}$ are observed that indicates the water-free topsoil layer. There are no moistening zones throughout the length of the profile.

\subsection{The results of visual examination}

The residential area was built after 1963. All the residential buildings of this area are located on the underworked territory of the former RKKA Mine. When carrying out a visual examination at the moment of work beginning, there was an increase in the subsidence cavity (the diameter increased to $10 \mathrm{~m}$ ). The cavity zone is identified by topsoil layer and sandy loam. The walls of the prospecting shaft are fastened by wooden prop stays. According to local residents the air pits, in some cases, are used as septic tanks.

With participation of detachment 19 of the Ministry of Emergency Situation of Dopropillia Town, a diagnosis of a collar of shaft fastening and the state of surrounding 
rocks has been carried out. With their participation, the actual dimensions of the air pit have been determined, where the technogenic disturbance has arisen and caving trough has been formed. It was established that the prospecting shaft has a wooden fastening with dimensions $2.8 \times 2.8 \mathrm{~m}$, the surface area along the caving contour is $52.8 \mathrm{~m}^{2}$ and the volume of caving sinkhole is $330 \mathrm{~m}^{3}$.

It was established that the process of caving sinkholes formation is multifaceted and depends on many factors. With that, the cavity formation process is possible in four different types. An advance prevention of cavities is possible only by observing the state of massif after the mine workings closure for a long period of time. The example of the cavity formation in Dobropillia City shows processes of displacements and karstification, leading to fall of large rock masses and the Earth's surface caving. This means the shafts (pits) liquidation without full backfilling, but fastened by concrete, armored concrete, and other types of mine fastening, with capping thickness of up to $45 \mathrm{~m}$ on the basis of assessment of the actual shaft fastening and the long-term stability of shaft bottom massif.

Analyzing the obtained results and considered standard technology for vertical mine workings liquidation $[3,4,17,18]$, the following conclusions have been made. The normative technological scheme for vertical mine working liquidation has to be carried out with the use of floor slab panel placed at parent rock level, with subsequent backfilling of the upper part of the shaft and construction of the second-floor slab.

The vertical mine workings liquidation technology consists of five main stages: preparation for filling; determination and outlining the boundaries of hazardous backfilling operations zone; surface preparation for filling; operation of pit shaft filling; completion of the final works. A waste rock of extinct mine dumps, sometimes more valuable materials extracted in quarries (breakstone, sand, gravel), as well as quick-cooled metallurgical slags are used for filling. The filling operations of the flooded shafts have to be carried out with the use of water-proofed material. It is forbidden to use a slag block (after disassembling of buildings) for cavity filling due to its toxicity.

The geologic data of prospecting the shaft location shows the presence of parent rocks at a depth more than $45 \mathrm{~m}$. It means that floor slab panel position at the level of parent rocks can cause an increase of caving trough up to $100 \mathrm{~m}$. But, in light of the fact, that technogenic disturbance has arisen in close proximity to residential buildings, the vertical mine working liquidation according to the normative technological scheme, will be costintensive.

Based on conclusions, the decision has been made to improve the liquidation technology of vertical mine working with a simultaneous liquidation of technogenic disturbance located in restricted sanitary protected zone of residential buildings. To achieve the solution of this problem, it is proposed to made a wedged choke with a pipe in the axis center of the liquidated mine working, with the subsequent void space filling (Fig. 3).

The quality control of backfilling material (grain size, density, etc.) and its volume have important implication while filling operations.

It is provided to mount the steel bearing frame (1) which will rest on the collar of prospecting shaft and cavity wall surfaces (Fig. 3) with further formation of a wedged choke. After concrete hardening (2), the caving trough is filled with rock-sand-sandy loam material in a volume of $300 \mathrm{~m}^{3}$ (4). In two months, the tamping and additional rock packing is carried out after slump of backfilling material under the action of environmental conditions, and the permanent floor slab panel installation is carried out (5).

In order to prevent the accumulation and explosion of methane in the prospecting shaft, it is necessary to drill a well and carry out the backfilling of mine working. In this view, the most appropriate means for backfilling is a conveyor, which ensures a slow and uniform flow of material, its packing and interaction with prospecting shaft fastening. When used a backfilling with hardening materials the pulp is supplied into the vertical mine working 
through pipes with diameter of $150-200 \mathrm{~mm}$, in volume of $300-320 \mathrm{~m}^{3}$. The technology of vertical mine working liquidation is shown in Fig 4.

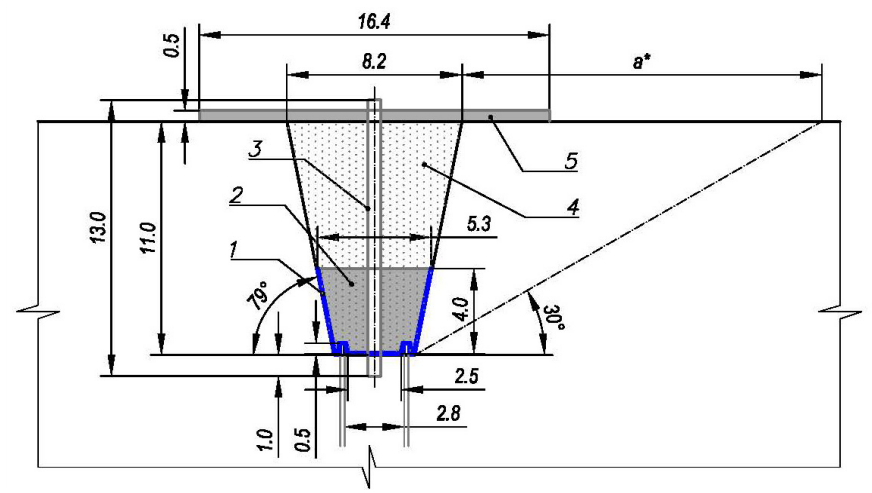

Fig. 3. The scheme of caving trough liquidation: 1 - steel bearing frame for collar of prospecting shaft, 2 - wedged choke $5.2 \times 5.2 \mathrm{~m}$ (concrete M 400), 3 - steel pipe $377 \times 9$ (State Standards of Ukraine 8732), 4 - rock-sand-sandy loam material, 5 - armored concrete floor $16.4 \times 16.4 \mathrm{~m}$ $(h=0.5 \mathrm{~m}), a^{*}-$ bankette of possible displacement $(a=17 \mathrm{~m})$.

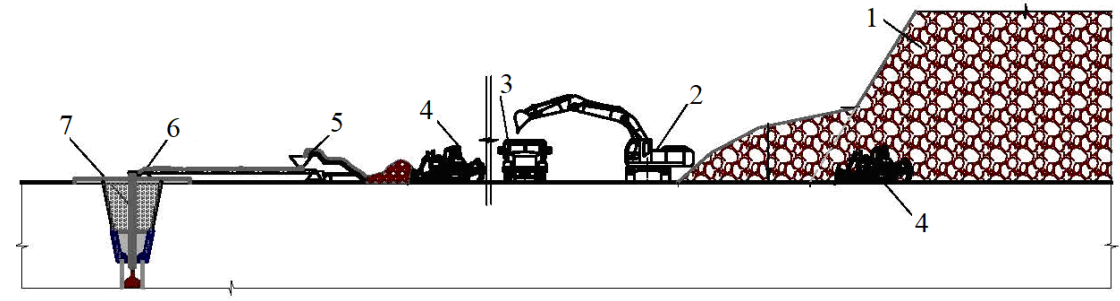

Fig. 4. The technological scheme of vertical mine working liquidation: 1 - waste-rock pile of "Almazna" Mine, 2 - mechanical shovel, 3 - dumping truck, 4 -bulldozer, 5 - stage loader, 6 - scraper conveyor, 7 - liquidated caving trough.

At the final stage, after slump of backfilling material, the covering of cavity collar and prospecting shaft is carried out. In world practice, the shaft collar is bridged over by a reinforced concrete slab with a focus on fasteners or poles hammered to the parent rocks. The construction of the slab, its thickness, cross sections, and bearing capacity are determined by practice and calculations. It is necessary to strengthen the rock massif preliminary in case of unsatisfactory prediction of collar stability. To exclude the possibility of rainwater and floodwater intake into liquidated prospecting shaft through collar, it should be protected by a drainage ditch of $2.5 \mathrm{~m}$ and with cross section $0.5 \mathrm{~m}^{2}$.

If it is difficult to implement the drainage of storm water and floodwater through the construction of a ditch, then it is advisable an application of an insulating shield of clay with a thickness of $1 \mathrm{~m}$ and an area by 1.5 times larger than the cross section of a shaft or a pit. In the future, according to the project, it is necessary to control constantly the backfilling material shrinkage and the release of methane on the surface of the yard.

\section{Conclusions}

In accordance with the research results, observations and their comparison with visual examination results, the following conclusions can be made: 
- the NPEFE observations in the cavity zone have shown that at the moment of examination there is no formed zone of soils moistening;

- based on the electric tomography method results, it was established the absence of loose, water-flooded zones located structurally below the cavity zone;

- in case of nonfulfillment of the measures for liquidation of the vertical shaft, the cavity zone will develop further, caused by soaking of overlaying rock massif and atmospheric precipitation, and this may result in the destruction of mine working support.

Based on the results of performed geophysical studies for identifying the cause and factors of the occurrence of technogenic disturbances that arose in the result of naturaltechnogenic processes activation in underworked massif and are caused by the soil subsidence under buildings and constructions, a technological scheme has been developed for caving trough liquidation in the conditions of restricted sanitary protected zone.

The developed new technological scheme allows conducting the effective liquidation works in conditions of proximity to the residential buildings and maximally reduces the scopes of works for caving trough liquidation due to the presented above technological system.

This work was carried out within the framework of a project of the technological scheme development for liquidation of caving trough in Dobropillia City (Ukraine), and was developed by the contract No. 010110-17. The authors are grateful to the management and employees of the detachment 19 of the Ministry of Emergency Situations in Dobropillia City for assistance in the investigation and detection of anthropogenic disturbance, as well as to Dr. Sc., prof. Pinkovskyi H.S. and Dr. Sc., prof. Bondarenko V.I, the management of DTEK "Dobropilliavuhillia" for providing scientific advice and recommendations.

\section{References}

1. Pivnyak, G.G., \& Shashenko, O.M. (2015). Innovations and safety for coal mines in Ukraine. Naukovyi Visnyk Natsionalnoho Hirnychoho Universytetu, (6), 118-121.

2. Bondarenko, V.I., Rudenko, H.K., \& Medyanik, V.Yu. (2017). Ugol'naya shahta. Dnipropetrovsk: Natsionalnyi hirnychyi universytet.

3. Bondarenko, V., Kovalevs'ka, I., \& Fomychov, V. (2012). Features of carrying out experiment using finite-element methodat multivariate calculation of mine massif - combined support system. Geomechanical Processes During Underground Mining, 7-13. https://doi.org/10.1201/b13157-3

4. Petlovanyi, M.V., Lozynskyi, V.H., Saik, P.B., \& Sai, K.S. (2018). Modern experience of lowcoal seams underground mining in Ukraine. International Journal of Mining Science and Technology. Article in press https://doi.org/10.1016/j.ijmst.2018.05.014

5. Chetverik, M.S., Bubnova, E.A., \& Soroka, Yu.N. (2013). Prichiny obrazovaniya i napravleniya likvidatsii provalov ot gornykh vyrabotok. Heotehnichna mekhanika, (111), 193-205.

6. Strilets, O., Pcholkin, G., \& Oliferuk, V. (2015). Monitoring of mass blasting seismic impact on residencial buildings and constructions. Theoretical and Practical Solutions of Mineral Resources Mining, 441-443.

7. Shirin, L.N., Denishchenko, A.V., Yurchenko, O.O., \& Mikhalev, D.V. (2012). Methodology for determination of rope vehicles energy consumption. Naukovyi Visnyk Natsionalnoho Hirnychoho Universytetu, (4), 464-469.

8. Cherniaiev, O.V. (2017). Systematization of the hard rock non-metallic mineral deposits for improvement of their mining technologies. Naukovyi Visnyk Natsionalnoho Hirnychoho Universytetu, (5), 11-17.

9. Shyrin, A., Rastsvetaev, V., \& Morozova, T. (2012). Estimation of reliability and capacity of auxiliary vehicles while preparing coal reserves for stoping. Geomechanical Processes during 
Underground Mining: School of Underground Mining 2012, 105-108. https://doi.org/10.1201/b13157-18

10. Huang, F., Luo, X., \& Liu, W. (2017). Stability Analysis of Hydrodynamic Pressure Landslides with Different Permeability Coefficients Affected by Reservoir Water Level Fluctuations and Rainstorms. Water, 9(7), 450. https://doi.org/10.3390/w9070450

11. Gorova, A., Pavlychenko, A., Kulyna, S., \& Shkremetko, O. (2012). Ecological problems of postindustrial mining areas. Geomechanical Processes During Underground Mining: School of Underground Mining 2012, 35-40. https://doi.org/10.1201/b13157-7

12. Gorova, A., Pavlychenko, A., Borysovs'ka, O., \& Krups'ka, L. (2013). The development of methodology for assessment of environmental risk degree in mining regions. Annual ScientificTechnical Collection - Mining of Mineral Deposits, 207-209. https://doi.org/10.1201/b16354-38

13. Falshtynskyi, V.S., Dychkovskyi, R.O., Saik, P.B., Lozynskyi, V.H., \& Cabana, E. (2017). Formation of thermal fields by the energy-chemical complex of coal gasification. Naukovyi Visnyk Natsionalnoho Hirnychoho Universytetu, (5), 36-42.

14. Lozynskyi, V., Dychkovskyi, R., Saik, P., \& Falshtynskyi, V. (2018). Coal Seam Gasification in Faulting Zones (Heat and Mass Balance Study). Solid State Phenomena, (277), 66-79. https://doi.org/10.4028/www.scientific.net/SSP.277.66

15. Bilyi Y.S., Dovbnich, M.M., Kuzina, G.P., \& Stovas, G.M. (2004). Sposib vydilennia na ploshchi dilianok neodnoridnoi budovy hruntovoho masyvu. Patent No. 64221, Ukraine.

16. DBN A.2.1-1-2014. (2014). Inzhenerno-geologicheskie izyskaniya dlya stroitelstva. Kyiv: Ukrayinskyi derzhavnyi holovnyi naukovo-doslidnyi i vyrobnychyi instytut inzhenernotekhnichnykh i ekolohichnykh vyshukuvan.

17. SOU 10.1.05400632.1:2004. (2004). Proekt likvidatsii vuhilnykh shakht Ukrainy.

18. Malashkevych, D., Sotskov V., Medyanyk V. \& Prykhodchenko D. (2018). Integrated Evaluation of the Worked-Out Area Partial Backfill Effect of Stress-Strain State of Coal-Bearing Rock Mass. Solid State Phenomena, (277), 213-220. https://doi.org/10.4028/www.scientific.net/ssp.277.213 